\title{
Comic-Based Learning Media with the Topic of Natural Resources
}

\section{Anak Agung Ayu Made Liniasari ${ }^{*}$, Kadek Yudiana ${ }^{2}$, I Ketut Dibia ${ }^{3}$}

1,2,3Jurusan Pendidikan Dasar, Universitas Pendidikan Ganesha, Singaraja, Indonesia

\begin{tabular}{l} 
A R T I C L E I N F O \\
\hline Article history: \\
22 December 2020 \\
Received in revised form \\
14 January 2021 \\
Accepted 15 January \\
2021 \\
Available online 25 \\
February 2021 \\
Kata Kunci: \\
Media Komik, Sumber \\
Daya Alam \\
Keywords: \\
Comic Media, Natural \\
Resources
\end{tabular}

\begin{abstract}
A B S T R A K
Keterbatasan media pembelajaran dalam proses pembelajaran utamanya dalam muatan ilmu pengetahuan sosial dengan topik sumber daya alam di kelas IV. Penelitian ini bertujuan untuk mengembangkan media pembelajaran berbasis komik yang valid. Model pengembangan yang digunakan adalah model ADDIE yang memiliki tahapan, yakni: analisis, perencanaan, pengembangan, implementasi, dan evaluasi. Produk media pembelajaran berbasis komik dijadikan subjek dalam penelitian ini, kemudian validitas media pembelajaran berbasis komik merupakan objek penelitiannya. Metode pengumpulan data dilakukan menggunakan metode kuesioner. Dalam mengukur validitas media pembelajaran berbasis komik, digunakan instrumen rating scale berupa lembar penilaian validitas media yang diisi oleh 1 dosen sebagai ahli materi dan 1 dosen sebagai ahli media dan 2 orang guru sebagai ahli praktisi. Data validitas media yang diperoleh selanjutnya dianalisis menggunakan rumus mean untuk mengetahui skor rata-rata validitas media pembelajaran berbasis komik. Skor rata-rata yang diperoleh masing-masing ahli pada ahli materi sebesar 4.80, ahli media sebesar 4.79, dan ahli praktisi sebesar 4.88, ketiga skor rata-rata yang diperoleh tergolong kategori "sangat baik". Berdasarkan
\end{abstract} hal tersebut maka media pembelajaran berbasis komik yang dikembangkan dengan topik sumber daya alam dinyatakan valid dan dapat digunakan dalam pembelajaran di kelas IV sekolah dasar.

\begin{abstract}
A B S T R A C T
The limitations of learning media in the learning process are mainly in the content of social studies with the topic of natural resources in grade IV. This study aims to develop a valid comic-based learning media. The development model used is the ADDIE model which has five stages, namely: analysis, planning, development, implementation, and evaluation. Comic-based learning media products were the subject of this study, then the validity of comic-based learning media was the object of research. The data collection method was conducted using a questionnaire method. In measuring the validity of comic-based learning media, a rating scale instrument is used in the form of a media validity assessment sheet filled in by 1 lecturer as a material expert and 1 lecturer as a media expert and 2 teachers as a practitioner expert. The media validity data obtained were then analyzed using the mean formula to determine the average score of the validity of comic-based learning media. The average score obtained by each expert on the material expert is 4.80, the media expert is 4.79, and the practitioner expert is 4.88, the three average scores obtained belong to the "very good" category. Based on this, the comic-based learning media developed on the topic of natural resources is declared valid and can be used in learning in grade IV elementary schools.
\end{abstract}

\section{Introduction}

Social Studies (IPS) is one of the subjects that must be taught in primary and secondary education. Social studies are needed as a forum for knowledge that harmonizes the pace of development of science and life in the world of school teaching. Social studies teaching usually highlights, discusses, and studies social symptoms or problems from various aspects of life, or interrelates various aspects of social life that discuss social problems or symptoms (Christina \& Kristin, 2016). Social studies learning in elementary schools is entegrated. IPS is used as knowledge that fosters future generations to learn positive things, namely by making changes according to the conditions desired by the world or in accordance with the creative power of development and the principles and value systems adopted by society and fostering a better future life for society. Social studies content has an ideal objective, namely to develop students' potential to be sensitive to social problems that occur in society, have a positive mental attitude towards correcting any imbalances that occur, and are skilled at overseeing every problem that occurs daily, 
whether that befalls themselves or those that affect life society, nation and state (Manu et al., 2021; Wahyu, 2018; Wei et al., 2021). So, it focuses more on students' experiences in facing a problem and can find solutions to these problems (Hawley \& Whitman, 2020; Lee et al., 2020).

Social studies learning problems that have been ongoing, include: 1) learning takes place in one direction, 2) there is no material connection with everyday life, 3) the use of learning media is still small (Meiarti \& Ellianawati, 2019; Turşucu et al., 2020). Based on the results of observations and interviews, the fourth grade teacher at SD Negeri 1 Megati, the implementation of learning was carried out based on the syllabus and lesson plans. The use of learning resources is guided by teacher books, student books and student worksheets (LKS) books. The use of learning media is still lacking and there are many learning media in schools that are not suitable or suitable for use in the learning process because many media are damaged and not all subjects have media, the material coverage is too dense with minimal resources which causes many female students to dislike social lessons. and consider it as one of the less preferred subjects in school (Syawaluddin et al., 2020). If this is allowed, students will lack teaching materials considering the material in social studies learning in elementary schools tends to be congested. In addition, learning is less effective, students easily get bored remembering that in Social Studies there are many materials that need to be memorized and have difficulty understanding learning, so that the learning objectives are not maximally achieved. Student motivation will also be low to participate in the learning process, through learning motivation students will be moved to follow it, and motivation is one of the goals of learning (Puspitarini \& Hanif, 2019). The implementation of social learning is only focused on improving cognitive aspects, such as memorizing a number of materials and text books so that it is fixated on social learning to become saturated learning and is considered unimportant by students. (Nugraha et al., 2018; Rosyida et al., 2018).

The solution that can be implemented is to use learning media, especially comics. Previous research stated that the development of comic media in social science subjects can attract students' interest to learn and is feasible to be applied as a learning media (Sukmanasa, et al., 2017). Other research results states that the use of comic media in social studies learning is effective in improving student learning outcomes, with very good qualifications (Boangmanalu, et al., 2018). The use of comic media in android-based development obtains a validation score of material and media experts which material experts are categorized as feasible. Meanwhile, the average result from media experts is very feasible (Lestari \& Projosantoso, 2016). Comics are effectively used in the learning process based on test results on student responses (Subroto \& Qohar, 2020). In addition, the weakness of the research that has been carried out beforehand, on average, the comics presented have the same plot from the beginning to the end of the story, the use of characters is still in the form of sketches without color and the delivery of examples or depictions of a concept is still in the form of full dialogue (Rina et al., 2020). To overcome these weaknesses, comic-based learning media were developed, which discussed natural resource materials that included the definition of natural resources, the use of natural resources, identification of the use of natural resources in the environment, and the characteristics of the use of natural resources in everyday life.

The development of comic-based learning media that has been developed has advantages including the use of various plot lines, the material presented is more attractive, each storyline in comics depicting characters that are adapted to the situation and conditions and in full color. In addition, examples and pictures are presented to support the explanation of the material presented with the help of visualization. Comic-based learning media on the topic of natural resources have never been developed. So that comic-based learning media is developed with the content of social science on the topic of natural resources in the fourth grade of elementary schools. By developing this media, it is hoped that learning will take place effectively and can attract students' interest to take part in the learning process. This study aims to develop comic-based learning media with the topic of natural resources in grade IV elementary schools whose validity has been tested. The implication of this research is the existence of comic-based learning media on social studies content on the topic of valid natural resources

\section{Method}

This study uses the ADDIE development model. This model was chosen because it has a systematic and clear stage in solving learning problems, so it will be good if it is applied as a development design. The ADDIE Development Model has five stages, namely: analyze, design, development, implementation, evaluation (Tegeh et al., 2014). The subject of the product trial was comic-based learning media on the topic of natural resources in grade IV elementary schools. The object of testing in this study is the validity of the developed comic-based learning media. There are two types of data obtained in this study. The data is qualitative data and quantitative data. Quantitative data were obtained through the 
review stage by experts. The quantitative data comes from the expert assessment sheet. The questionnaire method is used in data collection, the instrument used is a rating scale in the form of a comic-based learning media assessment sheet. The instrument used is a rating scale in the form of comic-based learning media assessment sheets. Comics have interrelated elements which include panels, viewpoints and image sizes, trenches, word balloons, sound illustrations, stories, splashes, motion lines, symbolia, and comic headers. (Yanti. et al., 2019). There are several comic elements poured into the instrument that are tailored to the needs of the media assessment to be made. These elements are outlined in the material aspects, material presentation, language, appearance, media presentation, and visuals that are described in the assessment for material experts, media experts and practitioner experts. The assessment for expert practitioners is a combination of assessments for material experts and media experts. The assessment instrument grid for material experts is presented in Table 1.

Table 1. Material Expert Instrument Grid

\begin{tabular}{ll}
\hline No $\quad$ Aspect & \multicolumn{1}{c}{ Description } \\
\hline $1 \quad$ Learning Material & The material presented in the media is in accordance with the \\
& basic competencies and learning objectives. \\
& The topics covered can be clearly understood. \\
& Material regarding natural resources is discussed in a coherent \\
& manner. \\
& Natural resource material has been thoroughly covered in the \\
& comic. \\
& Natural resource materials have been discussed thoroughly \\
& according to basic competency and learning objectives. \\
& Examples given in comics are in accordance with the material / \\
& topic. \\
& The materials and examples provided can foster students' \\
& independence in learning. \\
& The availability of comics can encourage student activity in the \\
& learning process. \\
& Clarity of presentation of attractive and proportional figures. \\
& The storyline presented supports the ease of the reader to \\
& understand the material. \\
& The terms displayed in the media correspond to the material. \\
& The use of language supports the ease of understanding the flow of \\
& the material. \\
& The use of language is in accordance with the abilities of \\
& elementary school students, especially in grade IV. \\
& Use of language that remains polite and does not reduce \\
& educational values. \\
& The dialogue text used in comics can convey the material \\
& appropriately. \\
\hline Language &
\end{tabular}

(Angga, et al., 2020, modified)

The assessment instrument grid for learning media experts is presented in Table 2 .

Tabel 2. Learning Media Expert Instrument Grid

\begin{tabular}{lll}
\hline No & Aspect & \multicolumn{1}{c}{ Description } \\
\hline 1 & Display & The image and cover design gives a positive impression so that it can \\
& attract readers. \\
& Book page designs have been organized and consistent. \\
& The selected font size and type is correct and makes the media more \\
& attractive. \\
& Text / writing is easy to read. \\
& The colors chosen and their combinations are appropriate and \\
& attractive. \\
& There is a suitability of the presentation of the image, the story line and \\
& the material being discussed.
\end{tabular}




\begin{tabular}{|c|c|c|}
\hline No & Aspect & Description \\
\hline 2 & Presentation of Media & $\begin{array}{l}\text { The print, finish, and comic binding are all done neatly. } \\
\text { The presentation of comic books is carried out coherently / } \\
\text { systematically. }\end{array}$ \\
\hline \multirow{9}{*}{3} & \multirow{9}{*}{ Visual } & $\begin{array}{l}\text { The presentation of the figures in each panel is attractive and } \\
\text { proportional. }\end{array}$ \\
\hline & & Character designs are presented attractively. \\
\hline & & The suitability of media illustrations with natural resource materials. \\
\hline & & The illustrations on the media are in accordance with the \\
\hline & & characteristics of elementary school students, especially grade IV. \\
\hline & & The background displayed on the media is in accordance with the \\
\hline & & The media layout is served accordingly. \\
\hline & & There is an integrated panel, word balloons, characters, and \\
\hline & & $\begin{array}{l}\text { illustrations so that the comics displayed are in accordance with the } \\
\text { proportions. }\end{array}$ \\
\hline
\end{tabular}

(Angga, et al., 2020, modified)

Before being tested in the study, the instruments used must be valid. In testing the validity of the contents of the instrument, a judges' test in its field is required. The content validity test in this study used the Gregory formula. Based on the content validity test, the content validity of the comic-based learning media instrument is 1.00 . The results of the content validity test showed that the content validity of the assessment instrument was in the very high category. In this study using qualitative descriptive statistical analysis methods and techniques and quantitative descriptive statistical analysis. Qualitative descriptive statistical analysis, this analysis method is used to process data in the form of criticism, suggestions, and input from expert reviews of comic-based learning media developed through questionnaires or questionnaires. The results of the analysis were then used to revise the comic-based learning media. Quantitative descriptive statistical analysis is used to describe the average score of the developed comicbased learning media. The average score for the validity of the developed media is obtained using the mean formula. The average score obtained is then converted using five scale conversion guidelines to determine the validity of the media being developed. The five scale conversion guidelines used are presented in Table 3.

Table 3. Five Scale Conversion Guidelines

\begin{tabular}{cc}
\hline Rentang Skor & Classification / Predicate \\
\hline $4,01<\mathrm{X} \leq 5,01$ & Very good \\
$3,33<\mathrm{X} \leq 4,01$ & Good \\
$2,66<\mathrm{X} \leq 3,33$ & Pretty good \\
$1,99<\mathrm{X} \leq 2,66$ & Bad \\
$0,99<\mathrm{X} \leq 1,99$ & Very bad \\
\hline
\end{tabular}

\section{Result and Discussion}

Source: (Koyan, 2012)

\section{Results}

Analyze stage consists of several parts, namely needs analysis, student characteristic analysis, curriculum analysis, and media analysis. The way to find out this is by making observations to grade IV teachers in elementary schools. Observations were directed at the availability of social science content material in student books and their development. The results of observations in the form of interviews with teachers showed that the material listed in the students' books was still shallow, especially the content of social science. The description of the material is usually only in the form of definitions and questions, rarely provides examples. Analysis of student characteristics is carried out to determine the characteristics of students who will use the media. Curriculum analysis is carried out through analysis of $\mathrm{KI}, \mathrm{KD}$, indicators and learning objectives. This curriculum analysis is seen from Permendikbud Regulation No. 24 of 2016 and the syllabus used in schools and the translation in student books and teacher books used during the learning process. The next stage is to compare with the material contained in student books and student worksheets used by students, especially the content of social science class IV with the topic of natural resources. After completion, the next stage is carried out, namely the design stage. 
The design stage (design), carried out the design of the media being developed. The media design uses the Adobe Illustrator 2020 application. The media design is then consulted with the supervisor for input and suggestions. Then proceed to the development stage that is adjusted to the good design of the character description, material and storyline. In the depiction of the character consists of four characters, namely Ayu, Sari, Agung and Pak Tarno. Ayu is described as a character who has a neat appearance with loose hair and clean skin. Sari is depicted as a character wearing a hijab, Agung is depicted as a man who has rapid hair and brown skin. Finally, Pak Tarno, who is described as a man in his 30s and works in a park. The story line is designed in the form of sketches of character layout positions and conversations, which aims to simplify and speed up the preparation of comics. The following is a sketch of the face of one of the characters and a sketch of the layout of the characters and the layout of the conversation Figure 1.

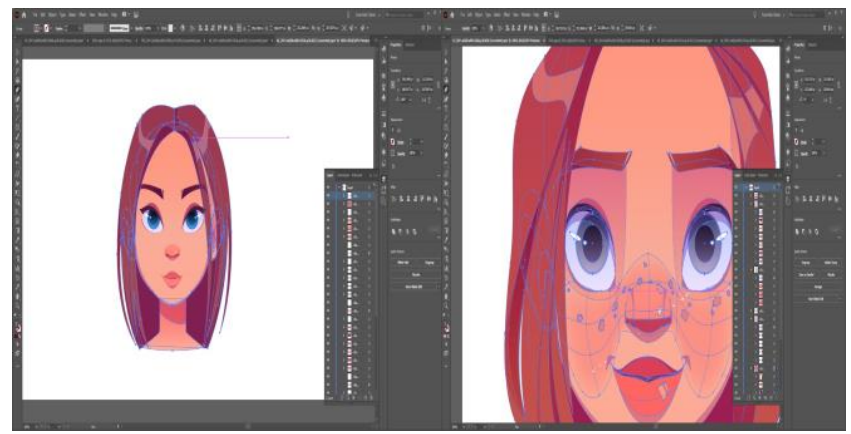

Face sketch

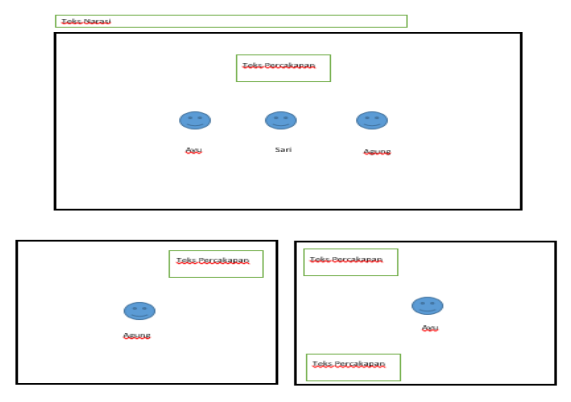

Layout

Figure 1. Face sketch and Layout

The development stage is carried out by developing the media in accordance with the design that has been approved by the supervisor. Implementation of development is carried out by creating attractive covers, characters, backgrounds, which are equipped with basic competencies, learning objectives, instructions for using media, and the identity of the author which is equipped on the back cover of the comic. then an assessment was carried out by two lecturers, one lecturer as a material expert and one lecturer as a media expert, and two teachers as an expert practitioner. The implementation of the assessment of the developed comics was given input by media and material experts, namely the use of colors on the front cover adjusted to the background and correcting the use of words, especially the wrong words and the choice of words according to the characteristics of students. The data obtained from expert judgment were then analyzed for their feasibility. The appearance of comic-based learning media on the topic of natural resources in grade IV elementary schools developed in Figure 2.

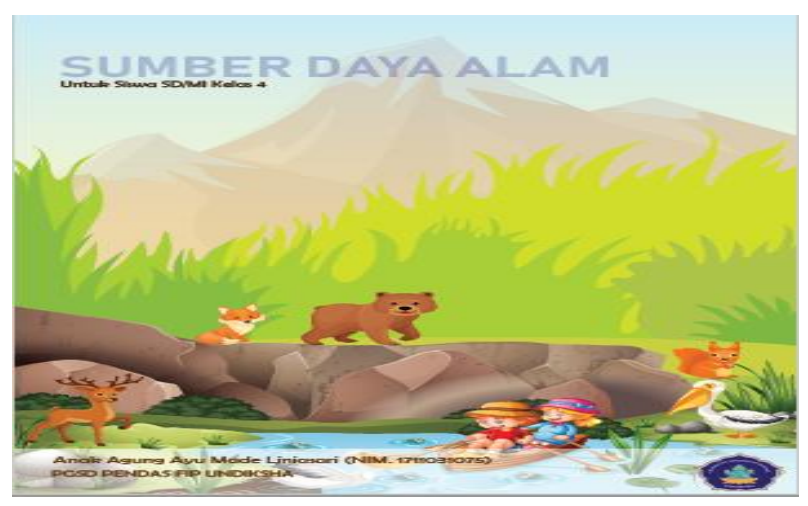

(a) front cover

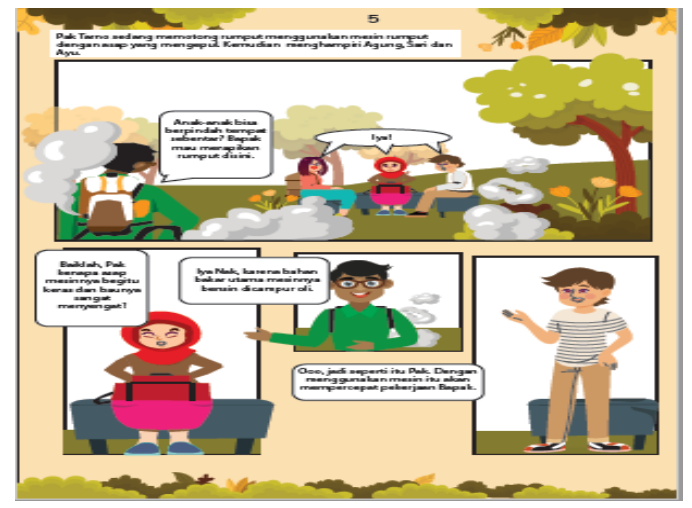

(b) contents 


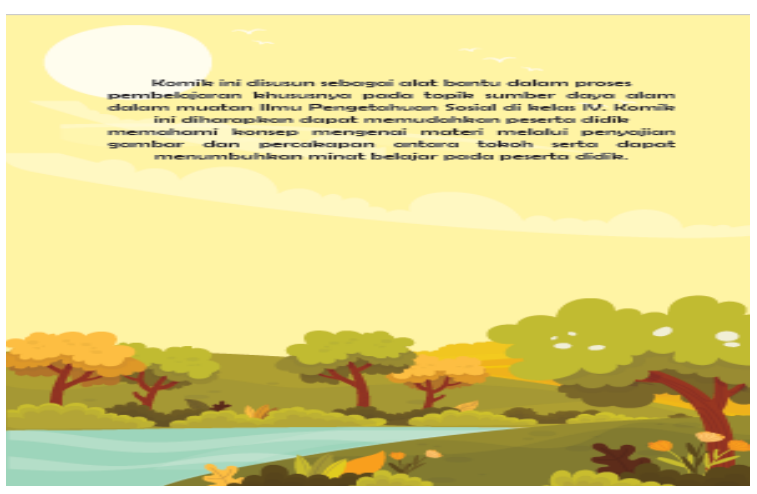

(c) cover

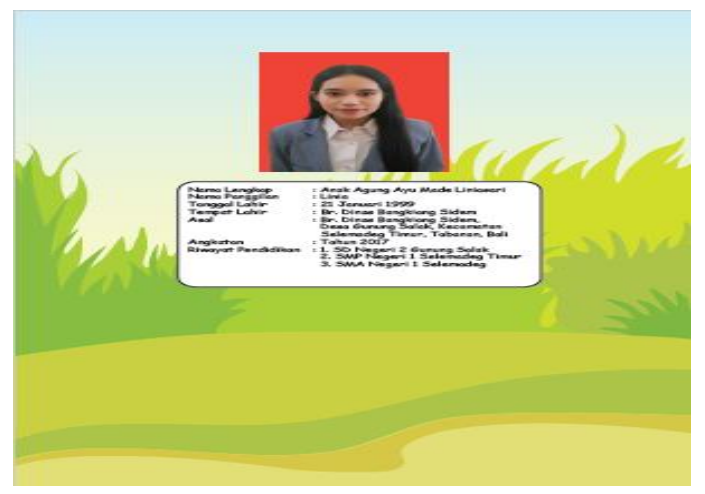

(d) back cover

Figure 2. Front cover, contents, cover and back cover

The last stage that is carried out after the media is finished is conducting media trials to determine the validity of the media developed using assessment instruments that have been tested by judges beforehand. The results of the validity of comic-based learning media with the topic of natural resources in grade IV elementary school material experts, media experts and practitioner experts are presented in Table 4.

Table 4. Results of the Validity of Comic-Based Learning Media

\begin{tabular}{ccc}
\hline No & Test Results & Mean \\
\hline 1 & Material Expert & 4.80 \\
2 & Learning Media Expert & 4.79 \\
3 & Practitioner & 4.88 \\
\hline
\end{tabular}

Based on the results of data analysis in the form of the average validity score of comic-based learning media from the four experts given by material experts of 4.80, media experts of 4.79, the two expert practitioners obtained 4.88. Of the three scores, when converted using a five-scale conversion, it is in the range $4.01<\mathrm{X} \leq 5.01$. Based on the results of the five-scale qualification, the comic-based learning media has a "very good" qualification. Based on the description of research results that have been used previously, the development of comic-based learning media uses the ADDIE model with the analyze, design, development, implementation, and evaluation stages. However, development is carried out until the development stage due to limited time, energy, resources, situations and conditions. The selection of this model is based on the ADDIE model which is developed systematically and rests on the foundation of learning design so that it is appropriate for use in the development of comic media.

\section{Discussion}

The development of comic-based learning media with the topic of natural resources is declared valid with very good qualifications. This is because the media developed is in accordance with the characteristics of students, namely it can present directly in the form of images combined with dialogue to form a story (Nugraheni, 2017; Rifky, 2017). This provides learners with learning experiences that can strengthen memory, clarify material and shape understanding. So, it can increase student motivation to learn it. In its presentation, comics are a form of pictorial news, consisting of various serial situations, arranged systematically, motivating students to improve learning outcomes (Untari \& Saputra, 2016). In addition, it can lead to activation in the learning process, this is because there is reciprocal interaction between teachers and students so that learning runs effectively (van der Kleij, 2019). The material contained in the media is in accordance with the level of education and the applicable curriculum and the presentation of the media is also interesting, full of colors, by recognizing colors, the senses of recognition of the child's brain will be stimulated, the concept of color in children is a form of basic learning so that children are more sensitive to objects in the environment, can also increase the mindset and creativity in children (Nityanasari, 2020). 
From the results of this study, comic-based learning media is very good, which means that it is suitable for use as a learning medium. In line with several previous research regarding the development of comics on learning content (Anesia et al., 2018; Hadi et al., 2019; Hands et al., 2018; Iskandar, 2019; Sridhar et al., 2017; Suryatin \& Sugiman, 2019). The novelty of the research developed lies in the content of comic-based learning media, where in addition to presenting conversations between characters it is also supported by explanations of examples through visualization. In addition, the depiction of the story in the comic is depicted in several different or varied settings so that it is more interesting.

Based on the theory of constructivism, students are able to shape their understanding in learning through the process of assimilation, accommodation, and equilibration. In constructivism theory emphasizes the learning process rather than learning material (Nugroho, 2016). The advantages of comicbased learning media are: it can facilitate understanding and strengthen memory; it can foster interest and provide a relationship between the content of the subject matter with the real world; the image quality in comics can improve the quality of the learning process (Anesia et al., 2018; Sari et al., 2019). Based on the advantages that have been described, the use of comic media can increase student interest which is supported by the existence of comics that are able to express visualized ones that can make readers emotionally involved, this results in students wanting to continue reading until finished (Islam, et al., 2018). In society, comics are so rampant and one's liking for comics is also quite high so that this is what becomes a guideline for comics to use as a learning medium (Prasetyo, 2018). In its presentation it is simple, and has elements of a story sequence that contains a message that is presented in a concise and easy to understand manner because it is combined with verbal language that is dialogue and sometimes humor (Beers Fägersten, 2017; Hardiyanti et al., 2019). This can help readers to understand the message in question and can provide an element of entertainment in conveying the message (Riwanto \& Wulandari, 2018). The implication of this research is that there is a comic-based learning media with the topic of natural resources in grade IV elementary schools in the form of interesting comic books consisting of social studies material and examples supported by pictures that are declared valid. Media that has been tested for its validity is certainly very suitable to be used as a tool in teaching and learning so that it can create quality learning.

\section{Conclusion}

Comic-based learning media that has been developed have been tested for validity. Comic-based learning media with the topic of natural resources in grade IV elementary schools in the form of interesting comic books consisting of social studies material and examples supported by pictures that are declared valid. Media that has been tested for its validity is certainly very suitable to be used as a tool in teaching and learning so that it can create quality learning.

\section{References}

F. Y., . D. H. M. S., \& . I. G. M. B. S. P. . M. P. (2019). Analisis Komik Web Karya Wildan Ridho Sajali. Jurnal Pendidikan Seni Rupa Undiksha, 9(1), 24. https://doi.org/10.23887/jjpsp.v9i1.18947.

Anesia, R., Anggoro, B. ., \& Gunawan, I. (2018). Pengembangan Media Komik Berbasis Android Pada Pokok Bahasan Gerak Lurus. Indonesian Journal of Science and Mathematics Education, 1(1), 53-57.

Angga, P. M. W., Sudarma, I. K., \& Suartama, I. K. (2020). E-Komik Pendidikan Untuk Membentuk Karakter Dan Meningkatkan Hasil Belajar Siswa Kelas V Pada Mata Pelajaran Bahasa Indonesia. Jurnal Edutech Undiksha, 8(2), 93. https://doi.org/10.23887/jeu.v8i2.28920.

Beers Fägersten, K. (2017). English-language swearing as humor in Swedish comic strips. Journal of Pragmatics, 121, 175-187. https://doi.org/10.1016/j.pragma.2017.10.014.

Christina, L. V., \& Kristin, F. (2016). Efektivitas Model Pembelajaran Tipe Group Investigation (Gi) Dan Cooperative Integrated Reading and Composition (Circ) Dalam Meningkatkan Kreativitas Berpikir Kritis Dan Hasil Belajar Ips Siswa Kelas 4. Scholaria: Jurnal Pendidikan Dan Kebudayaan, 6(3), 217. https://doi.org/10.24246/j.scholaria.2016.v6.i3.p217-230.

Hadi, Y. A., Husni, M., \& Pazri, R. (2019). Pengembangan Komik Sebagai Media Pemeblajaran Ilmu Pengetahuan Sosial (IPS) Kelas IV SDN 2 Selong. Jurnal DIDIKA: Wahana Ilmiah Pendidikan Dasar, 5(2), 113. https://doi.org/10.29408/didika.v5i2.1784.

Hands, T., Shaw, A., Gibson, M., \& Miller, K. (2018). People and their plants: The effect of an educational comic on gardening intentions. Urban Forestry and Urban Greening, 30(June 2017), 132-137. https: //doi.org/10.1016/j.ufug.2018.01.017.

Hawley, T. S., \& Whitman, G. M. (2020). Fear and learning in student teaching: Accountability as gatekeeper in social studies. Journal of Social Studies Research, 44(1), 105-115. 
https://doi.org/10.1016/j.jssr.2019.04.003.

Iskandar, R. (2019). Pengembangan Media Pembelajaran Ips Berbasis Komik Di Sekolah Dasar. Jurnal Ilmiah Pendidikan Guru Sekolah Dasar, 3(2), 237-246.

Lee, M. J., Wu, W. C., Chang, H. C., Chen, H. J., Lin, W. S., Feng, J. Y., \& Lee, T. S. H. (2020). Effectiveness of a school-based life skills program on emotional regulation and depression among elementary school students: A randomized study. Children and Youth Services Review, 118(September), 105464. https://doi.org/10.1016/j.childyouth.2020.105464.

Lestari, D. I., \& Projosantoso, A. K. (2016). Pengembangan Media Komik IPA Model PBL untuk Meningkatkan Kemampuan Berfikir Analitis dan Sikap Ilmiah Developing Science Comic Media Using the Problem-Based Learning Model to Increase the Analytical Thinking Ability and Scientific Attitude. Jurnal Inovasi Pendidikan Ipa, 2(2), 145-155.

Manu, B. D., Ying, F., Oduro, D., \& Boateng, S. A. (2021). Student engagement and social media in tertiary education: The perception and experience from the Ghanaian public university. Social Sciences \& Humanities Open, 3(1), 100100. https://doi.org/10.1016/j.ssaho.2020.100100.

Meiarti, D., \& Ellianawati, E. (2019). Mind Mapping Based Creative Problem Solving: Train The Creative Thinking Skills of Vocational School Students in Physics Learning. Jurnal Penelitian \& Pengembangan Pendidikan Fisika, 5(2), 91-100. https://doi.org/10.21009/1.05204.

Nityanasari, D. (2020). Alat Permainan Edukatif Pasak Warna Untuk Meningkatkan Kemampuan Mengenal Warna Pada Anak Usia Dini. Pendidikan Anak Usia Dini, 4(1), 10.

Nugraha, Y. A., Handoyo, E., \& Sulistyorini, S. (2018). Traditional Game on The Social Skill of Students in The Social Science Learning of Elementary School. Journal of Primary Education, 7(2), 220-227. https://doi.org/10.15294/jpe.v7i2.23475.

Nugraheni, N. (2017). Penerapan Media Komik Pada Pembelajaran Matematika Di Sekolah Dasar. Refleksi Edukatika : Jurnal Ilmiah Kependidikan, 7(2), 111-117. https://doi.org/10.24176/re.v7i2.1587.

Nugroho, S. A. (2016). Peningkatan Keaktifan dan Hasil Belajar Siswa Melalui Penerapan Teori Konstruktivisme Berbasis Media Wondershare Quizcreator. Indonesian Journal of Curriculum and Educational Technology Studies, 4(2), 73-78. https://doi.org/10.15294/ijcets.v4i2.14310.

Prasetyo, S. (2018). Kontribusi Pengembangan Media Komik Ipa Bermuatan Karakter Pada Materi Sumber Daya Alam Untuk Siswa Mi/Sd. Al-Bidayah: Jurnal Pendidikan Dasar Islam, 9(2), 75. https://doi.org/10.14421/jpdi.2017.0902-07.

Pratama, Y. A. (2018). Media Komik Dalam Pembelajaran Pendidikan Agama Islam Di Sdn 1 Sukabumi Bandar Lampung. Jurnal MUDARRISUNA: Media Kajian Pendidikan Agama Islam, 8(2), 347. https://doi.org/10.22373/jm.v8i2.4123.

Puspitarini, Y. D., \& Hanif, M. (2019). Using Learning Media to Increase Learning Motivation in Elementary School. Anatolian Journal of Education, 4(2), 53-60. https://doi.org/10.29333/aje.2019.426a.

Rifky, H. \&. (2017). Pengembangan media pembelajaran berbasis komik pada mata pelajaran ilmu pengetahuan sosial kelas IV MI Nurul Hidayah Roworejo Negerikaton Pesawaran. Jurnal Pendidikan Dan Pembelajaran Dasar, 4(1), 34-46.

Rina, N., Suminar, J. R., Damayani, N. A., \& Hafiar, H. (2020). Character education based on digital comic media. International Journal of Interactive Mobile Technologies, 14(3), 107-127. https://doi.org/10.3991/ijim.v14i03.12111.

Riwanto, M. A., \& Wulandari, M. P. (2018). Efektivitas Penggunaan Media Komik Digital (Cartoon Story Maker) dalam Pembelajaran Tema Selalu Berhemat Energi. Pancar, 2(1), 14-18.

Rosyida, A., Mustaji, M., \& Subroto, W. (2018). The Development of Contextual Teaching and Learn-ingBased Comic as a Learning Media for Elementary School Students. 173(Icei 2017), 13-16. https://doi.org/10.2991/icei-17.2018.4.

Sari, W. S., Hartika, L. D., Putu, N., \& Eka, R. (2019). STATISTIKA. October 2018.

Sridhar, A., Brown, A., \& Roque, K. (2017). Theory Based Educational Comic for Intrauterine Device Information: Perspectives of Primary Care Providers. Journal of Pediatric and Adolescent Gynecology, 30(2), 282-283. https://doi.org/10.1016/j.jpag.2017.03.034.

Subroto, E. N., \& Qohar, A. (2020). Efektivitas Pemanfaatan Komik sebagai Media Pembelajaran Matematika. 2006, 135-141.

Sukmanasa, E., Windiyani, T., \& Novita, L. (2017). Pengembangan Media Pembelajaran Komik Digital Pada Mata Pelajaran Ilmu Pengetahuan Sosial Bagi Siswa Kelas V Sekolah Dasar Di Kota Bogor. Jurnal Pendidikan Sekolah Dasar, 3(2), 171. https://doi.org/10.30870/jpsd.v3i2.2138.

Suryatin, S., \& Sugiman, S. (2019). Comic book for improving the elementary school students' mathematical problem solving skills and self-confidence. Jurnal Prima Edukasia, 7(1), 58-72. https://doi.org/10.21831/jpe.v7i1.10747.

Syawaluddin, A., Afriani Rachman, S., \& Khaerunnisa. (2020). Developing Snake Ladder Game Learning 
Media to Increase Students' Interest and Learning Outcomes on Social Studies in Elementary School. Simulation and Gaming, 51(4), 432-442. https://doi.org/10.1177/1046878120921902.

Tegeh, I. M., Jampel, I. N., \& Pudjawan, K. (2015). Pengembangan Buku Ajar Model Penelitian Pengembangan dengan Model ADDIE. Seminar Nasional Riset Inovatif IV, 208-216.

Turşucu, S., Spandaw, J., \& de Vries, M. J. (2020). Search for Symbol Sense Behavior: Students in Upper Secondary Education Solving Algebraic Physics Problems. Research in Science Education, 50(5), 2131-2157. https://doi.org/10.1007/s11165-018-9766-z.

Untari, M. F. A., \& Saputra, A. A. (2016). Keefektifan Media Komik Terhadap Kemampuan Membaca Pemahaman Pada Siswa Kelas Iv Sd. Mimbar Sekolah Dasar, 3(1), 29-39. https://doi.org/10.17509/mimbar-sd.v3i1.2354.

van der Kleij, F. M. (2019). Comparison of teacher and student perceptions of formative assessment feedback practices and association with individual student characteristics. Teaching and Teacher Education, 85, 175-189. https://doi.org/10.1016/j.tate.2019.06.010.

Wahyu B.S. (2018). Pengaruh kemampuan pedagogik guru dengan hasil belajar ips. Ilmiah Edutecno, 18(106), 1-19.

Wei, X., Lin, L., Meng, N., Tan, W., Kong, S. C., \& Kinshuk. (2021). The effectiveness of partial pair programming on elementary school students' Computational Thinking skills and self-efficacy. Computers and Education, 160, 104023. https://doi.org/10.1016/j.compedu.2020.104023. 